\title{
Isolation and characterization of gut-associated microbes in cockroach
}

\author{
US Bagde ${ }^{1 *}$, Uma Gopi ${ }^{1}$ and Ram Prasad ${ }^{2}$ \\ ${ }^{1}$ Applied Microbiology Laboratory, Department of Life Sciences, University of Mumbai, Vidyanagari, Santacruz (East), \\ Mumbai 400098, India. \\ ${ }^{2}$ Amity Institute of Microbial Technology, Amity University Uttar Pradesh, Sector 125, Noida-201303, India.
}

Accepted 19 April, 2013

\begin{abstract}
Arthropods, particularly insects form successful highly symbiotic relationship with endosymbiotic bacteria. The associations between insects and endosymbionts are remarkably stable; many stretch back several hundred million years in evolutionary time. Insects are amongst the most successful of animals, both in terms of diversity and in colonizing all ecological niches. The aim of this study was to isolate and identify microbes that were collected from the guts of cockroach Periplanata americana.
\end{abstract}

Key words: Periplanata americana, microorganisms, bacteria, fungi.

\section{INTRODUCTION}

Cockroaches are among the most notorious pests of premises, which not only contaminate food by leaving droppings and bacteria that can cause food poisoning but also they transmit bacteria, fungi and other pathogenic microorganisms in infested areas (Kopanic, 1994; Czajka et al., 2003; Salehzadeh et al., 2007; Vazirianzadeh et al., 2009). Cockroaches are basically omnivorous and feed indiscriminately on garbage and sewage and so have copious opportunity to disseminate human pathogens (Cotton et al., 2000; Pai et al., 2005). So far, numerous pathogenic bacteria, including Salmonella spp, Shigella spp, Campylobacter spp, Pseudomonas aeruginosa and Klebsiella pneumoniae have been isolated from cockroaches. In addition, some parasites and fungi have been found in bodies of cockroaches (Thyssen et al., 2004; Fotedar and Banerjee, 1992).

The goal of this study was to isolate and identify microorganisms associated with guts of the cockroach Periplaneta americana, using classical microbiological methods. This information will provide the basis for subsequent studies on the roles of these microorganisms in cockroach development and its ecological management.

\section{MATERIALS AND METHODS}

Collection and processing of cockroach samples

The cockroaches were collected from houses spread over the residential areas in metropolis. A transparent cylindrical plastic container with an opening of $11 \mathrm{~cm}$ in diameter and a lid was used to trap the cockroaches. The inside of the container was lined with blotting paper smeared with petroleum jelly. The trap was kept in the kitchen or other strategic part of the house overnight, uncovered. The following day, the container was covered and transported to the laboratory.

Surface sterilization of cockroach

In the laboratory, each cockroach was washed with $70 \%$ ethanol in a sterile conical flask (to decontaminate external surfaces as $70 \%$ ethanol is bactericidal), transferred to sterilized flasks, and allowed to dry at room temperature under sterile conditions.

\section{Dissection of the cockroach}

The cockroach was dissected in $10 \mathrm{mM}$ sterile phosphate-buffered saline (PBS) inside a sterile laminar flow hood using dissection scissors and fine-tipped forceps. The cockroach was placed in 
Table 1. Organisms isolated from the cockroach gut.

\begin{tabular}{lll}
\hline Isolated microorganisms & cockroach gut & Present species \\
\hline & Fore gut & $\begin{array}{l}\text { Escherichia coli, Enterobacter aerogenes, Salmonella para typhi B, } \\
\text { Shigella dysenterae, Staphylococcus aureus, Bacillus species. }\end{array}$ \\
Bacteria & Mid gut & $\begin{array}{l}\text { Escherichia coli, Enterobacter aerogenes, Salmonella typhi, } \\
\text { Salmonella para typhi B, Staphylococcus aureus, Bacillus species. }\end{array}$ \\
& Hind gut & Staphylococcus aureus, Bacillus species. \\
& Fore gut & Fusarium species, Saccharomyces cerevisae. \\
Fungi & Mid gut & Aspergillus niger, Penicillium species. \\
& Hind gut & Aspergillus niger, Penicillium species.
\end{tabular}

wax tray fixed with pins and the cockroach was dissected. The antennae were cut, then the two pairs of wings. Then the sides were trimmed to facilitate removal of the tergal integuments. Before the integuments were removed the legs were also cut off. Care was taken so as not to break the gut or to cut off any other tissue associated with the gut.

\section{Isolation and identification of microorganisms from gut}

Alimentary canal of $P$. americana starts with oesophagus followed by crop, gizzard, eccentric caeca, foregut, midgut, malphigan tubules, hind gut, rectum and rectal papilla. From the alimentary canal guts were carefully cut and separated. After complete removal, the whole gut was placed in a Petri plate containing sterile distilled water or a saline solution. After being immobilized at $0^{\circ} \mathrm{C}$, the gut of the cockroach was dissected out and macerated aseptically in a sterile pestle and mortar in $2 \mathrm{ml}$ of sterile normal saline. Each part of the gut was then homogenized separately and the homogenate was used as an inoculum. The inoculation was done in flasks containing various media that is, nutrient broth, sabourauds dextrose broth and other enrichment and selective media to isolate specialized group of organisms. These flasks were then kept for incubation and the medium inside was used as an inoculums for further isolation and identification.

\section{Quantitative analysis of bacterial isolates}

Quantitative analysis of bacteria (Escherichia coli, Enterobacter aerogenes, Salmonella para typhi B, Shigella dysenterae, Staphylococcus aureus, Bacillus species) isolated from gut of cockroach was carried out. Each gut was placed in $100 \mu \mathrm{l}$ of $10 \mathrm{mM}$ PBS. A fixed volume (100 $\mu \mathrm{l}$ each) of the washing was cultured on blood agar, nutrient agar, MacConkey agar plates separately, incubated overnight at $37^{\circ} \mathrm{C}$ for 2 to 3 days; bacterial colonies were categorized based on morphology and counted across all plates on the three lowest countable dilutions. Pure cultures of bacterial isolates were obtained and used in further analyses and the colonies identified by standard bacteriological procedures (Baron and Finegold, 1990). In each case, a representative colony was classified according to its microscopic morphology, its Gram's staining, various biochemical and other specific characters. The results were read and colonies identified after overnight incubation at $37^{\circ} \mathrm{C}$.

\section{Fungal staining and microscopic observation}

The fungi cultured in Sabraud's Dextrose broth were transferred to potato dextrose agar with $0.5 \%$ chloramphenicol (Fotedar et al., 1991). The Petri plates were incubated at $30^{\circ} \mathrm{C}$ and the result was identified by standard mycological methods (Evans and Richardson, 1989). The cultures were examined after staining (0.1\% Trypan blue in Lactophenol) under light microscopy and identified (Beaver et al., 1984).

\section{RESULTS AND DISCUSSION}

It is observed that alimentary canal of $P$. americana consist of oesophagus followed by crop, gizzard, eccentric caeca, foregut, midgut, malphigan tubules, hind gut, rectum and rectal papilla. Cockroach gut is divided into three parts; fore gut- commonly concerned with storage of food and sometimes helps to fragment the food before it is passed to the mid gut. It is ectodermic in origin. The pharynx is the first part of the foregut following on buccal cavity. Oesophagus passes food back from pharynx to the crop. In crop, the food is stored and it may also serve as site for digestion. The mid gut is lined by a delicate membrane and is primarily concerned with the production of enzymes and the absorption of the products produced during digestion. It is chief locus for producing digestive enzymes for absorption and thus enabling digestion also. Hind gut- conducts undigested food to the exterior via the anus. The hind gut consists of pylorus, ileum and rectum. The microflora present in the guts of cockroaches that had been obtained from the domestic environment was studied. Test cockroaches were shown to carry various microorganisms (bacteria, fungi and yeast), some of them of medical importance. However, numbers of cockroaches collected from residential areas showed bacterial and fungal contamination.

Cockroach gut is divided into three guts. Fore gut is commonly concerned with storage of food, mid gut is primarily concerned with the production of enzymes and hind gut- conducts undigested food to the exterior via the anus. The cockroach gut has a varied micro flora which includes bacteria, fungi and yeast (Table 1). The tendency of cockroaches to move freely and inhabit toilets, sewers and drains create variety of sanitary 


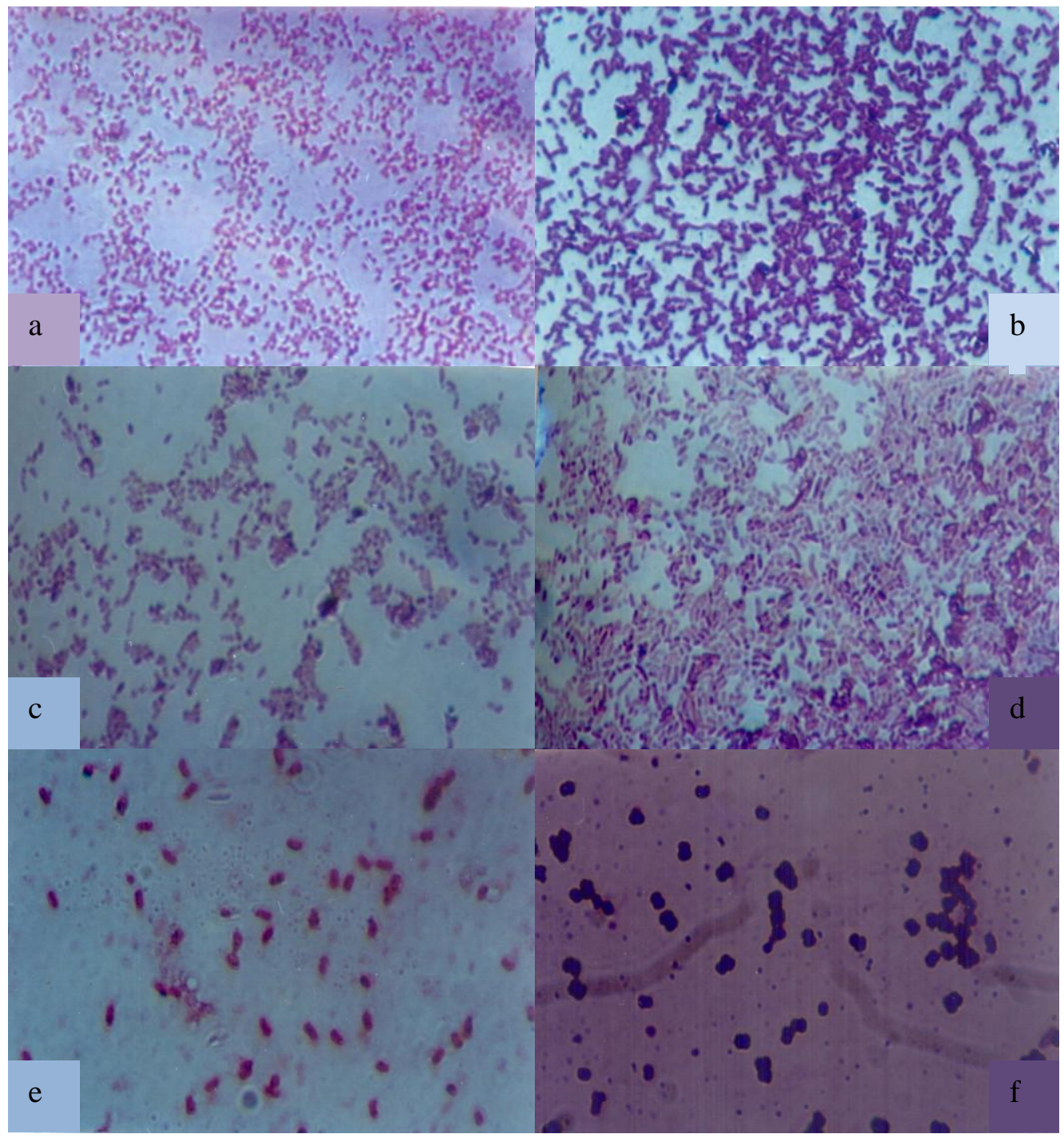

Figure 1. Microscopic analysis of b acteria. E coli (a), Enterobacter aerogenes (b), Salmonella para typhi B (c), Salmonella typhi (d), Shigella dysenteriae (e) and Staphylococcus aureus (f).

problems. For the identification of bacterial isolates, morphological, structural and colony characteristics were taken into consideration. The bacteria identified were as follows Escherichia coli, Enterobacter aerogenes, Salmonella typhi, Salmonella para typhi B, Shigella dysenterae, Staphylococcus aureus and Bacillus species (Figure 1 and Table 2). Bacterial identification was carried out by referring to Bergey's manual (Bergeys, 1974). The presence of all these symbionts in the cockroach gut have a varied influence on the host and affect the host in metabolic and physiological aspects, some are harmful causing diseased condition either alone or by combining with other organisms in the gut. They also benefit the host by providing them with some vital nutrients for their various activities. Among the bacteria isolated and studied, the family Enterobacteriaceae contained many species that are associated with the plants and animals. These bacteria are either saprophytic or pathogenic in nature.

Fungal identification was done by streaking a loopful of the inoculum growing in Sabraud's Dextrose broth and potato dextrose agar (Hi Media, India) plates. The plates were incubated for 3 to 5 days at room temperature and colony characteristics were studied. Assays were carried out for detecting the production of enzymes like amylase and cellulase. The fungal identification was carried out by referring to book on fungi by Alexopoulos et al. (1996). The fungi isolated from the cockroach gut belonged to the species of Saccharomyces cerevisae, Fusarium sp., Penicillium sp. and Aspergillus niger (Figure 2). Several species of fungi have been isolated and reported in the gut of the worker termite which included Cunninghamella echinulala, Aspergillus flavus, Aspergillus nidulans, Fusarium monilifrmis, Penicillum sp. (Rajgopal et al., 
Table 2. Description of the organisms isolated from the cockroach gut.

\begin{tabular}{|c|c|c|}
\hline Bacteria & Media & Colony characteristic features. \\
\hline \multirow{3}{*}{ Escherichia coli } & Nutrient agar & $\begin{array}{l}\text { Pin point, circular, whitish, entire, flat, translucent and moist } \\
\text { colonies. }\end{array}$ \\
\hline & Mc Conkey Agar & $\begin{array}{l}\text { Pin point, circular, pink colored, entire, elevated, opaque and moist } \\
\text { colonies. }\end{array}$ \\
\hline & Eosine Methylene Blue & $\begin{array}{l}\text { Pin point, circular, pinkish, entire, flat, translucent, greenish metallic } \\
\text { sheen and moist colonies. }\end{array}$ \\
\hline \multirow{3}{*}{ Enterobacter aerogenes } & Nutrient agar & $\begin{array}{l}\text { Small, circular, whitish, entire, elevated, translucent and moist } \\
\text { colonies. }\end{array}$ \\
\hline & Mc Conkey Agar & $\begin{array}{l}\text { Pin point, circular, pink, entire, elevated, translucent and moist } \\
\text { colonies. }\end{array}$ \\
\hline & Eosine Methylene Blue & $\begin{array}{l}1 \mathrm{~mm} \text {, circular, pink, entire, elevated, translucent and mucoid } \\
\text { colonies. }\end{array}$ \\
\hline \multirow{3}{*}{ Salmonella typhi } & Nutrient agar & $1 \mathrm{~mm}$, circular, whitish, entire, flat, translucent and moist colonies. \\
\hline & Mc Conkey Agar & $\begin{array}{l}\text { Pin point, round, creamish white, entire, flat, translucent and moist } \\
\text { colonies. }\end{array}$ \\
\hline & Salmonella Shigella Agar & Pin point, black, opaque, regular. \\
\hline \multirow{3}{*}{ Salmonella para typhi B } & Nutrient agar & $\begin{array}{l}\text { Pin point, circular, whitish entire margin, translucent and moist } \\
\text { colonies. }\end{array}$ \\
\hline & Mc Conkey Agar & Pin point, round, yellowish, flat, translucent and irregular colonies. \\
\hline & Salmonella Shigella Agar & Black, opaque regular colonies. \\
\hline Shigella dysenterae & $\begin{array}{l}\text { Nutrient agar } \\
\text { Mc Conkey Agar } \\
\text { Salmonella Shigella Agar }\end{array}$ & $\begin{array}{l}\text { Pin point, circular, white, entire, smooth, colorless, flat, translucent. } \\
\text { Pin point, round, colorless, translucent, butyrous, irregular flat. } \\
<1 \mathrm{~mm} \text {, round, colorless, opaque, flat, irregular, butyrous. }\end{array}$ \\
\hline \multirow{2}{*}{ Staphylococcus aureus } & Nutrient agar & $\begin{array}{l}1 \text { to } 2 \mathrm{~mm} \text {, round, golden yellow, regular, raised, opaque, butyrous } \\
\text { colonies. }\end{array}$ \\
\hline & Blood agar plates & Golden yellow without haemolysis. \\
\hline Bacillus species & Nutrient agar & 1 to $2 \mathrm{~mm}$, round, irregular, flat, moist, opaque colonies. \\
\hline
\end{tabular}

1979). A. niger, A. Aspergillus fumigatus and Rhizopus species are common environmental contaminants which the cockroaches may have acquired as they run over surfaces. Contamination of food by these toxin producing fungi have been reported with grave consequences to susceptible individuals (Lewis et al., 2005). The microorganisms play an important role in the gut of the insect and they derive benefit from the host. The cellulose digesting groups of micro-organisms play a major role in the insects including cockroaches, beetles, termites and wood wasps. In rotting wood and vegetation, cellulose fermenting bacteria are always present and they form an important element in the diet of the insects feeding on cellulosic materials occurring in the gut (Pochon, 1939). Cleveland (1935) stated that cockroaches depend for the decomposition of their cellulose on bacteria in the crop. It 


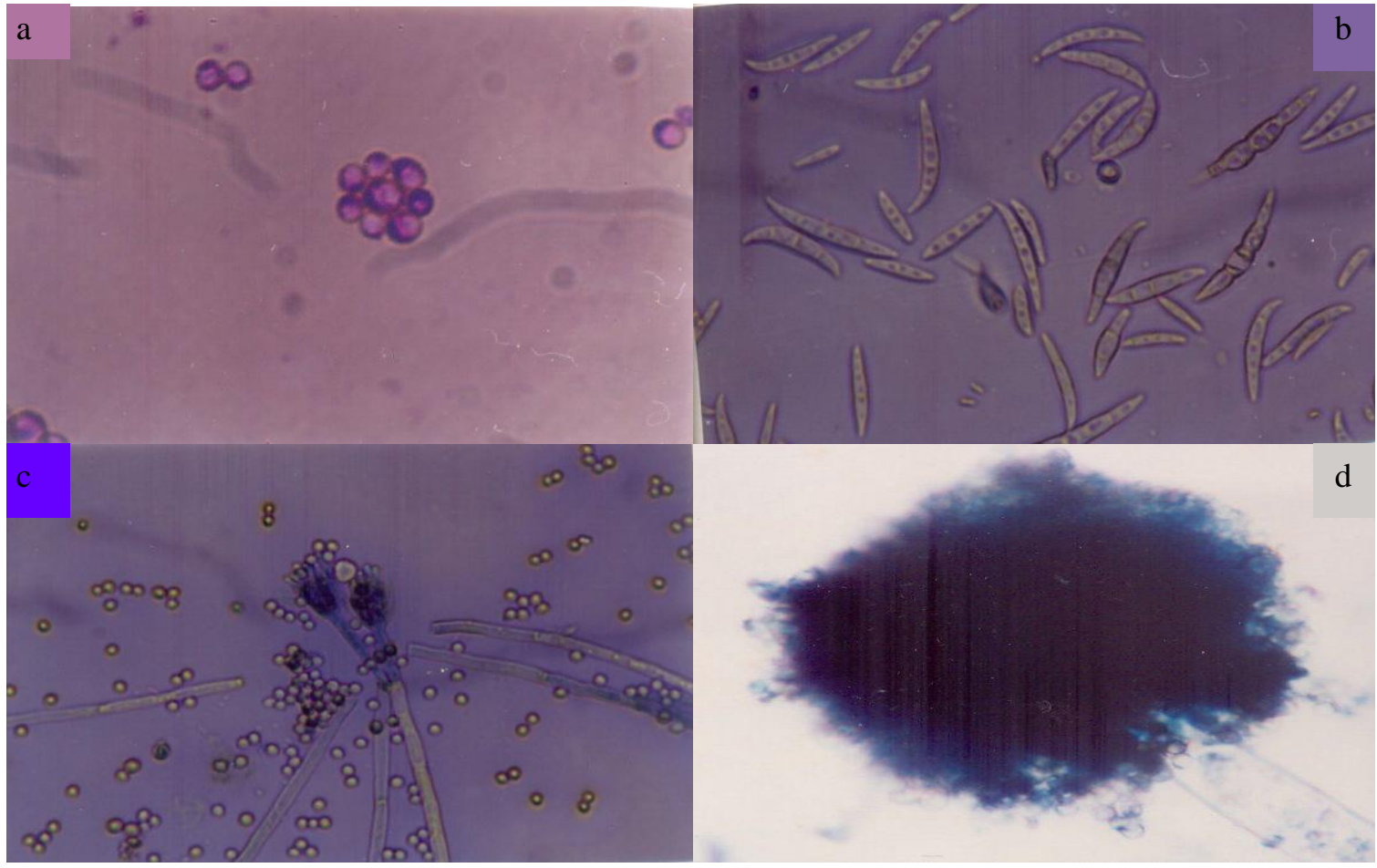

Figure 2. Microscopic analysis of Fungus. Saccharomyces cerevisae (a), Fusarium sp. (b), Penicillium sp. (c) and Aspergillus niger (d).

has also been observed that normal inhabitants of the insects, that is the normal microbial flora help to confer on its host immunity to infection by related organisms. In cockroach, the hind gut is a significant site of absorption for symbiotically digested cellulose. The insect can make up for cellulase deficiency either by cultivating hind-gut protozoa or using cellulase of ingested fungi (Daw, 1986). Thus, the bacteria, fungi and protozoa play an important role in the digestion of cellulose which provides as a source of nutrients to the host. Many of the organisms isolated from the gut also elaborated cellulase and digested cellulose.

In the present study conducted, cellulolytic and amylolytic bacteria and fungi have been reported. They elaborated enzymes like cellulase and amylase which is required to digest cellulose and starch respectively. This is in agreement to similar studies conducted earlier (Rajagopal, 2009). The presence of lysozyme in the insect gut protects the insect from the numerous bacteria it consumes with food (Tanada and Kaya, 1993). Thus, the insects and the microorganisms inhabiting the gut share a highly symbiotic relationship and in colonizing all ecological niches (Gibson and Hunter, 2010; Harris et al., 2010).

\section{REFERENCES}

Alexopoulos CJ, Mims CW, Blackwell M (1996). Introductory Mycology. John Wiley and Sons, Inc, New York.
Baron EJ, Finegold SM (1990). Bailey and Scott's diagnostic microbiology, VIII edn. St. Louis: Mosby Co. 323-861.

Beaver PC, Jung RC, Cupp EW (1984). Clinical Parasitology. IX edn. Philadelphia: Lea and Febiger.

Bergeys (1974). Manual of systematic bacteriology. 1:67, 71, 811, 828.

Cleveland (1935). Protozoa and bacteria cellulose digestion cryptocerus panesthia, Blattidae. Mem. Ameriana Acad. Arts Sci. 17:185.

Cotton MF, Wasserman E, Pieper CH, Van Tubbergh D, Campbell G, Fang FC, Barnes J (2000). Invasive disease due to extended spectrum beta-lactamase-producing Klebsiella pneumoniae in a neonatal unit: the possible role of cockroaches. J. Hosp. Infect. 44:13-7.

Czajka E, Pancer K, Kochman M, Gliniewicz A, Sawicka B, Rabczenko D, Stypulkowska-Misiurewicz H (2003). Characteristics of bacteria isolated from body surface of German cockroaches caught in hospitals. Przegl. Epidemiol. 57: 655-62.

Daw J (1986). Insects in mid-gut function: Advances in insect physiology. Academic press 296-301.

Evans EGV, Richrdson MD (1989). Medical mycology: a practical approach. Oxford: Oxford University Press.

Fotedar R, Banerjee U (1992). Nosocomial fungal infections- study of the possible role of cockroaches (Blattella germanica) as vectors. Acta Trop. 50:339-43.

Fotedar R, Shriniwas UB, Verma A (1991). Cockroaches (Blattella germanica) as carriers of microorganisms of medical importance in hospitals. Epidemiol. Infect. 107:181-187.

Gibson CM, Hunter MS (2010). Extraordinarily widespread and fantastically complex: comparative biology of endosymbiotic bacterial and fungal mutualists of insects. Ecol. Lett. 13:223-234.

Harris HL, Brennan LJ, Keddie BA, Braig HR (2010). Bacterial symbionts in insects: balancing life and death. Symbiosis 51:37-53.

Kopanic RJ (1994). Cockroaches as vectors of Salmonella: laboratory and field trials. J. Food Prot. 57:25-32.

Lewis L, Onsongo M, Njapau $H$ (2005). Aflatoxin contamination of commercial maize products during an outbreak of acute aflatoxicosis in eastern and central Kenya. Environ. Health Perspect. 113(12): 
1763-1767.

Pai HH, Chen WC, Peng CF (2005). Isolation of bacteria with antibiotic resistance from household cockroaches (Periplaneta americana and Blattella germanica). Acta Trop. 93:259-65.

Pochon F (1939). Cellulose digesting bacteria. C.R. Acad. Sci. 208:1684-1686.

Rajagopal R (2009). Beneficial interactions between insects and gut bacteria. Indian J. Microbiol. 49:114-119.

Rajgopal S, Rao DR, Varma AK (1979). Association of fungi in termite gut. Curr. Sci. 48:998-999.

Salehzadeh A, Tavacol P, Mahjub H (2007). Bacterial, fungal and parasitic contamination of cockroaches in public hospitals of Hamadan, Iran. J. Vect. Borne Dis. 44:05-110.

Tanada Y, kaya H (1993). Insect pathology. Academic Press 21-27, $502,506$.
Thyssen PJ, Moretti T deC, Ueta MT, Ribeiro OB (2004). The role of insects (Blattodea, Diptera, and Hymenoptera) as possible mechanical vectors of helminths in the domiciliary and peridomiciliary environment. Cad. Saude. Publica. 20:1096-102.

Vazirianzadeh B, Mehdinejad M, Dehghani R (2009). Identification of bacteria which possible transmitted by Polyphaga aegyptica (Blattodea: Blattidae) in the region of Ahvaz, SW Iran. Jundishapur J. Microbiol. 2(1):36-40. 